\section{Effect of scandium additions on pressure less sintering of Al-TiN metal matrix composites}

SARTHAK KHARE - National Institute of Technology, Jamshedpur - sarthakjsr@gmail.com MUNISH SHARMA - National Institute of Technology, Jamshedpur - sharma.munish14@gmail.com K. VENKATESWARLU - Hindustan Aeronautics Limited (NAL), Bangalore

Received: 13.10.2009. - Érkezett: 2009.10.13. http://dx.doi.org/10.14382/epitoanyag-jsbcm.2010.8

Synthesis Al-TiN (10, 20, 30 wt\%) composites without and with Scandium (Sc) (0.2 and 0.6 wt\%) have been prepared using pressure less sintering. An amount of $4 \mathrm{wt} \% \mathrm{Cu}$ is added in all the samples for the better wettability purpose. Powders of Al, $\mathrm{Cu}$ and TiN are mixed thoroughly and compacted to pellets of $12 \mathrm{~mm}$ diameter and $4 \mathrm{~mm}$ thickness. Samples of Al-TiN are sintered at 450,550 and $620^{\circ} \mathrm{C}$ in a controlled atmosphere tubular furnace purged with Ar gas. The hardness results suggest that samples sintered at $620^{\circ} \mathrm{C}$ and higher TiN contained samples exhibited higher hardness values. The samples sintered at other temperatures showed abrupt hardness values which suggest that the sintering temperatures are not sufficient for complete sintering. Further sintering was carried out at $620^{\circ} \mathrm{C}$ for scandium added Al-TiN composites. The results suggest that the $0.2 \% \mathrm{Sc}$ additions did not show significant improvement in microstructure and hardness. But the samples with $0.6 \%$ scandium showed significant improvement in hardness and very fine grain structure with very good interfacial bonding between the matrix and the TiN particles. The Al-0.6Sc-30TiN composite showed the best hardness and microstructure of all the tested samples. The wear behavior of the developed composites indicated that the scandium additions not only showed significant improvement in microstructure and improved hardness results but also exhibited superior wear resistance properties.

\section{Introduction}

In the recent past, extensive research work has been carried out and it is shown that there is tremendous promise of ceramic reinforced metal-matrix composites (MMCs) [1-3]. Processing techniques have been developed to synthesize the MMCs for diverse field of applications [1,2] in aerospace, defense, automobile and sports sectors. In MMCs, addition of a small amount of second phase materials with high shear strength was added to the base materials to obtain unique properties [4-6]. Among the various MMCs, Al based MMCs have received much attention due to their light weight, strength to weight ratio, ease in melting and casting and most abundantly available raw materials. Most of the research on the Al based composites is to improve its mechanical properties by the incorporation of hard ceramic oxides (carbides) nitrides into the metal matrix. Powder metallurgy route has been extensively studied. Another route of synthesizing of MMCs is by liquid metallurgy route, where the reinforcing phases are either infiltrated [7-9] or injected into the liquid metal. Mixing, in-situ growth and spray forming techniques are also used to prepare the MMCs. The spray forming of composite involves spraying of both liquid metal and reinforcing particulates simultaneously [10]. Among various ceramic additions to $\mathrm{Al}$, $\mathrm{SiC}$ has been given much attention by many researchers and the synthesizing of Al-SiC MMCs is still has some limitations [1] and hence efforts are made to overcome the problems by incorporating other reinforcing materials such as $\mathrm{TiN}$ [11] and also to study the sintering behavior in pressure less conditions. In the recent past, the present authors had studied the sintering behavior of these composites at hot pressing conditions [12].

\section{Experimental procedure}

Dr. K. VENKATESHWARLU

is senior scientist at National Aeronotical Laboratory (NAL), Banglore, India. He has done his M.Tech and Phd from Indian Institute of Technology, Kharagpur, India. Beside his small stint at Regional Research Laboratory (RRL), Bhopal, India, he was associated with a resarch program at National Metallurgical Laboratory (NML), Jamshedpur, India, on advanced materials. He has more than 100 national and international publications.

SARTHAK KHARE Fellow of Bechlore of Technology (B.Tech) Hons program from National Institute of Technology, Jamshedpur. Apart from this, he is a core research team member at the same institute. For more than three years, has been working at National Metallurgical Laboratory (NML), Jamshedpur. He is a member of Indian Institute of Metals (IIM) and Indian Ceramic Society. He has various national and international publications in his account.

MUNISH SHARMA is fellow of Bechlore of Technology (B.Tech) Hons program from National Institute of Technology, Jamshedpur. Apart from this, he is a core research team member at the same institute. For more than two years, has been working at National Metallurgical Laboratory (NML), Jamshedpur. He is a member of Indian Institute of Metals (IIM). He has various national publications in his account.

Aluminum powder of $99.7 \%$ purity, copper of $99.5 \%$ purity and TiN powders were selected as the starting materials. Hereafter, \% is always reported as wt $\%$ only. The preparation of TiN powder is by selecting Ti sponge ( $>98 \%$ pure) and nitriding the same at $1823 \mathrm{~K}$ for $45 \mathrm{~min}$ and after nitridation; the lumpy mass was manually ground to yield powder by using an agate mortar. The powder was again nitrided and reground to ensure complete nitridation of Ti and the formation of a single-phase TiN powder [12]. Al powder (commercial purity) was prepared by atomization technique in our laboratory using a graphite nozzle of $3 \mathrm{~mm}$ diameter and at a gas pressure of $50 \mathrm{psi}$ and sieved to -300 mesh $(<53 \mu \mathrm{m})$. Copper powder $(-300$ mesh and 99.5\% pure) was used to improve the wettability of $\mathrm{Al}$ and TiN. Required amounts of $\mathrm{Al}$, TiN and $\mathrm{Cu}$ powders were taken in three separate batches with the compositions given in Table 1. The powder mixture was thoroughly mixed by hand using agate motor and cylindrical pellets of diameter $22 \mathrm{~mm}$ were made by applying load of $200 \mathrm{MPa}$. Subsequently, the pellets were transferred to a tubular furnace where temperatures of 450, 550 and $620^{\circ} \mathrm{C}$ and $\mathrm{Ar}$ atmosphere were maintained. The sintered samples were polished and prepared for hardness determination and metallographic examination. Bulk hardness of Al-TiN composite was determined using Vickers hardness tester at $5 \mathrm{~kg}$ load. The samples were etched with Kellers reagent $\left(2.5 \mathrm{ml} \mathrm{HCl}, 1.5 \mathrm{ml} \mathrm{HNO}_{3}\right.$ and $1 \mathrm{ml} \mathrm{HF}$ and rest is $\mathrm{H}_{2} \mathrm{O}$ ) and examined under SEM (JEOL 840A, Japan make). Dry sliding wear test was carried out on a pin-on-disc wear test machine (TR 20 LE, DUCOM make, Bangalore, India) with 
a sample of $8 \mathrm{~mm}$ diameter and $40 \mathrm{~mm}$ length. The diameter and height of the sintered sample was 8 and $5 \mathrm{~mm}$ respectively. The sample size requirement for conducting the sliding wear test is $40 \mathrm{~mm}$ height. Therefore, the sintered pellet was made to $40 \mathrm{~mm}$ height by attaching a steel sample of similar diameter. The specimens were allowed to slide against a rotating EN 32 steel disc (counter face) of hardness $65 \mathrm{Rc}$, where co-efficient of friction, and wear loss in microns were monitored as a function of load (1.5 and $2.5 \mathrm{~kg}$ ) up to $3200 \mathrm{~m}$ sliding distance.

\section{Results and discussion}

Initially, samples $\mathrm{A}, \mathrm{B}, \mathrm{C}$ are sintered at 450,550 and $620^{\circ} \mathrm{C}$ for $20 \mathrm{~min}$ holding time. Since the proper sintering was not observed for samples that are sintered at 450 and $550{ }^{\circ} \mathrm{C}$, all the remaining sintering tests are carried out at $620{ }^{\circ} \mathrm{C}$ only for all the alloys. Fig. 1. shows the XRD pattern of Al-10TiN, Al-20TiN and Al-30TiN, and marked as A, B and C respectively. XRD studies suggest that intensity of $\mathrm{Al}$ peak decreased and TiN intensity is increased with the increase in TiN content. In addition, $\mathrm{Al}_{2} \mathrm{Cu}$ peaks also have been observed since $4 \%$ of $\mathrm{Cu}$ is added to all the samples. Further, the results suggest that only $\mathrm{Al}$ and $\mathrm{Cu}$ are reacted and there is no product of $\mathrm{Cu}$ with TiN.

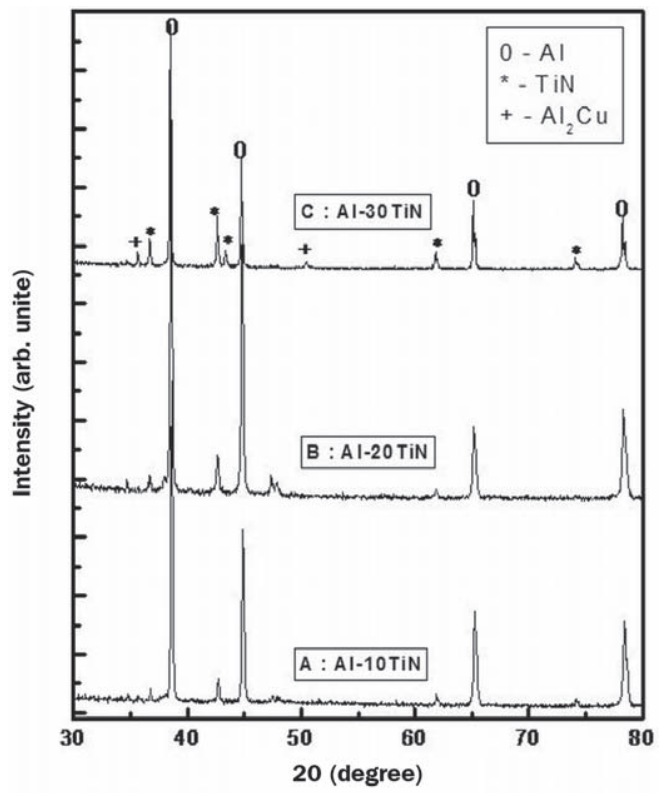

Fig.1. XRD pattern of samples $A-C$

1. ábra AzA-C minták röntgen diffraktogramjai

Table 1. shows the chemical composition and various identifications for each sample of all the experimental alloys. Similarly Table 2 . shows the density and hardness values for the Al-TiN MMCs with and without Sc contents (samples A-I). It is seen that there is no significant change in the density of samples D, E, F as compared to A, B, C samples. A nominal improvement in hardness measurements is noticed for samples $\mathrm{D}, \mathrm{E}$ and $\mathrm{F}$. However, significant change in the density and hardness values are observed for samples G, H and I when the Sc content is enhanced to $0.6 \%$ (Table 2.). From our earlier studies also, the grain refinement of Sc addition of CPAl suggest that there is no affect of Sc additions below 0.5\% [15]. Hence the present results are also in conformity with our earlier studies.

\begin{tabular}{cccc}
$\begin{array}{c}\text { Sample } \\
\text { designation }\end{array}$ & Al & TiN & Cu \\
A & 86 & 10 & 4 \\
\hline B & 76 & 20 & 4 \\
\hline C & 66 & 30 & 4 \\
\hline Al-0.25Sc & TiN & Cu \\
\hline D & 86 & 10 & 4 \\
\hline E & 76 & 20 & 4 \\
\hline F & 66 & 30 & 4 \\
\hline Al-0.6Sc & TiN & Cu \\
\hline H & 86 & 10 & 4 \\
\hline I & 76 & 20 & 4 \\
\hline
\end{tabular}

Table 1. Sample designation and composition for all the experimental alloys 1. táblázat A kísérleti minták jelölése és összetétele

\begin{tabular}{ccc} 
Sample designation & Density, g/cc & Hardness $\left(\mathbf{H}_{\mathbf{v}} \mathbf{5}\right)$ \\
\hline A & 2.59 & 57 \\
\hline B & 2.67 & 61 \\
\hline C & 2.78 & 72 \\
\hline D & 2.58 & 59 \\
\hline E & 2.70 & 64 \\
\hline F & 2.87 & 75 \\
\hline G & 2.65 & 68 \\
\hline H & 2.77 & 77 \\
\hline I & 2.86 & 90
\end{tabular}

Table 2. Density and hardness values for all experimental alloys 2. táblázat A kísérleti minták sürüsége és keménysége
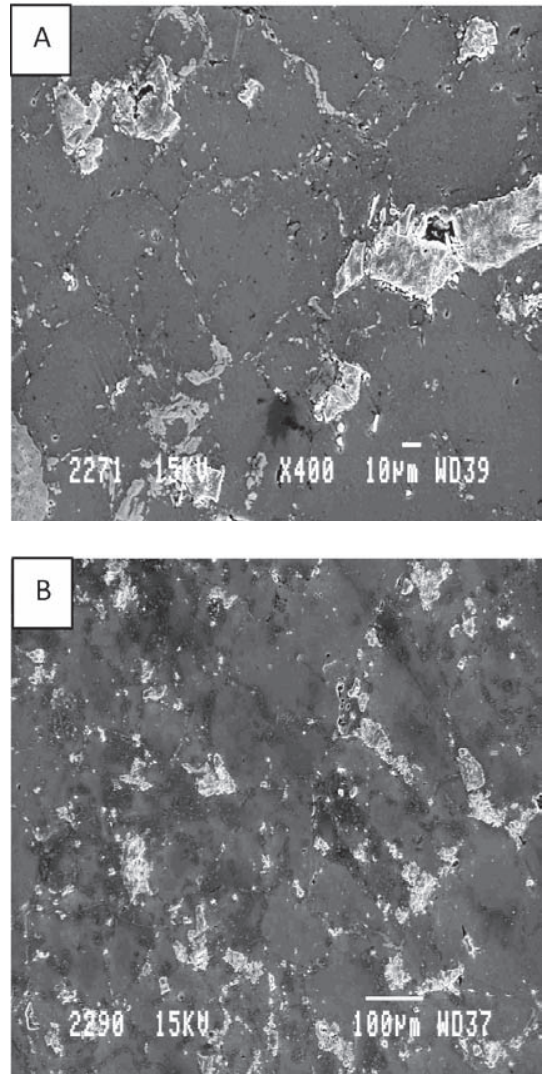

Fig. 2. SEM images of (A) Al-10TiN-4Cu and (B) Al-0.25Sc-10TiN samples 2. ábra AzAl-10TiN-4Cu (A) és az Al-0,25Sc-10TiN (B) minták pásztázó elektronmikroszkópos felvételei 

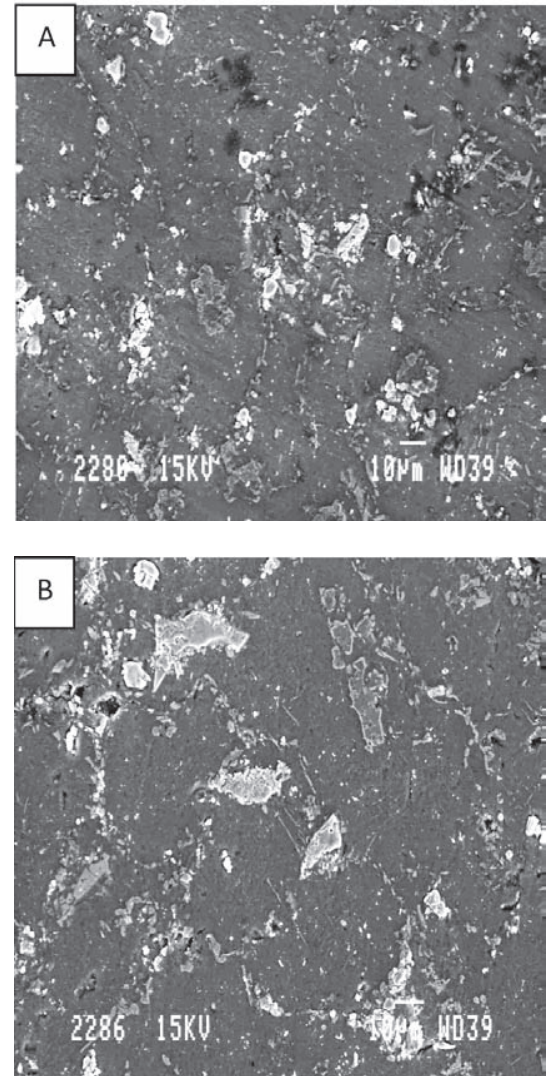

Fig. 3. SEM images of (A) Al-0.6Sc-20TiN-4Cu and (B) Al-0.6Sc-30TiN-4Cu samples

3. ábra Az Al-0,6Sc-20TiN-4Cu (A) és az Al-0,6Sc-30TiN-4Cu (B) minták pásztázó elektronmikroszkópos felvételei

Fig. 2. A, B shows the SEM images of sample A and D. Some black spots are clearly observed between the two TiN particles and are confirmed to be pores (Fig. 1. A). The bright particles are mostly in the range of $40-45 \mu \mathrm{m}$ are confirmed as TiN particles and the grey color small particles $\sim 5 \mu \mathrm{m}$ that are along the grain boundaries are observed as $\mathrm{Al}_{2} \mathrm{Cu}$ particles. Some amount of agglomeration of $\mathrm{TiN}$ particles is observed and this is possibly occurred during sintering process. The volumetric concentration of $\mathrm{Al}_{2} \mathrm{Cu}$ particles are lower as compared to TiN particles and the presence has been already confirmed from our XRD studies. The microstructural studies further confirm that the TiN particulates are uniformly distributed in the Al matrix. The volume concentrations of TiN particles are increased as the TiN content is increased from 10 to $30 \%$ (not shown here). Fig. 2. B shows the presence of few small particles and are possibly $\mathrm{Al}_{3} \mathrm{Sc}$ precipitates. In addition to the $\mathrm{Al}_{2} \mathrm{Cu}$ particles at grain boundaries, TiN particles also have been precipitated along the grain boundaries. This has a prolonging effect of interlocking of $\mathrm{Al}$ grains which, along with the difference in thermal expansion co-efficient of $\mathrm{Al}$ and TiN [14], strength of composite is boosted and it becomes slightly brittle. In view of understanding the effect of higher Sc additions, $0.6 \%$ is added to $\mathrm{Al}-4 \mathrm{Cu}-\mathrm{TiN}$ samples and Fig. 3. A, B shows the SEM images of $G$ and $H$ samples respectively. As expected, more TiN particles are in sample-H (Fig. 3. B) as compared to sample-G (Fig. 3 A). However, more refined microstructure is observed in these cases as compared to samples D-F. This directly suggests that Sc has significantly refined the microstructure and this has directly influence on the hardness values also. Sample A had the density of $2.59 \mathrm{~g} / \mathrm{cc}$ where as the sample I has $2.86 \mathrm{~g} / \mathrm{cc}$. This higher density is due to the Sc additions and refined structure that ahs led to less porosity levels and ahs direct influence on the density and hardness values. Sample A has the hardness values of 57 and sample $\mathrm{C}$ has $76 \mathrm{HV}$. This is due to higher concentration of TiN content whereas sample I gave $90 \mathrm{HV}$ as compared to sample $\mathrm{C}(76 \mathrm{HV})$. This is due to the grain refinement affect due to Sc additions. In order to confirm the presence of $\mathrm{Sc}, \mathrm{Cu}$ and $\mathrm{Ti}$, EDX has been carried out on the sample $\mathrm{H}$ and the pattern is shown in Fig. 4. It can be clearly seen from this pattern that $\mathrm{Al}, \mathrm{Ti}, \mathrm{Cu}$ and $\mathrm{Sc}$ elements are present and are in appropriate quantities. When scanning is done on the grey particles, only $\mathrm{Cu}$ and $\mathrm{Al}$ peaks are observed and from the concentration levels, the particles can be confirmed as $\mathrm{Al}_{2} \mathrm{Cu}$. Similarly, TiN and $\mathrm{Al}_{3} \mathrm{Sc}$ also confirmed from the EDX studies (respective patterns are not shown here). Fig. 5. shows the SEM image of sample I where one TiN particle at higher magnification. A close observation of this image suggests that there is absolutely no interfacial deboning between the matrix and the particle. When compared to sample $\mathrm{C}$, the porosity levels also very low for sample I.

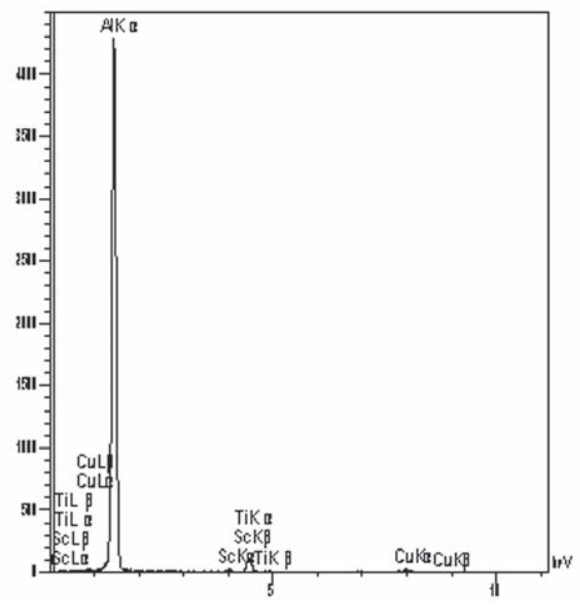

Fig. 4. EDX pattern on the sample I

4. ábra Az I minta elektrondiffrakciós képe

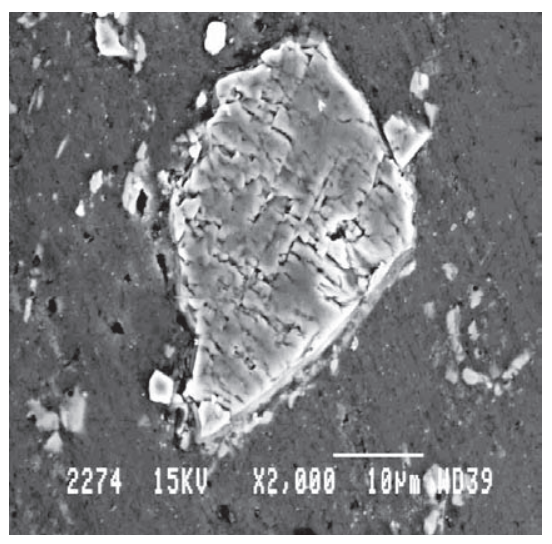

Fig. 5. SEM image of Al-0.6Sc-30TiN-4Cu at higher magniifcation 5. ábra Az Al-0,6Sc-30TiN-4Cu minta nagyobb nagyitású pásztázó elektronmikroszkópos felvétele 


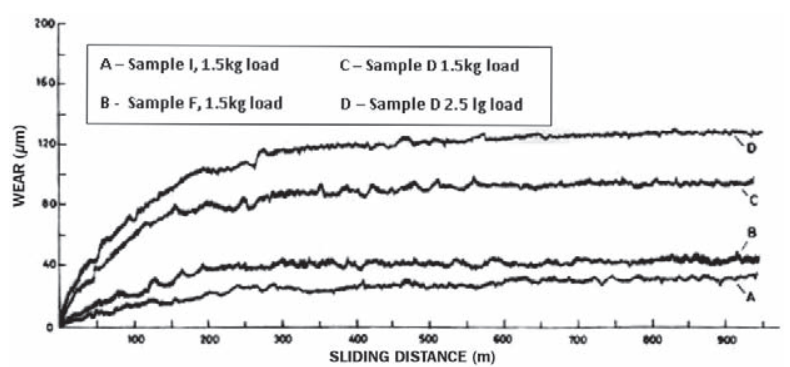

Fig. 6. Sliding wear performance of Al-TiN MMCs under different condiitons

6. ábra Az Al-TiN fémmátrixú társított anyagok csúszási kopása különbözö körülmények között

Fig. 6. shows the sliding wear performance of samples D and I. In case of sample D the response of load is clearly shown in the Fig. 6. C, D. It can be seen from this graph; the wear is linearly increased up to the sliding distance of $150 \mathrm{~m}$ and followed continuously up to $950 \mathrm{~m}$. The sample D experienced a total wear loss of $\sim 75 \mu \mathrm{m}$ at $1.5 \mathrm{~kg}$ load (Fig. 6. C) and further increase in load to $2.5 \mathrm{~kg}$, the total wear loss is $\sim 115 \mu \mathrm{m}$ (Fig. 6 . D). However when the TiN concentration is high, i.e. in sample $\mathrm{I}$, the sliding wear response is different. In fact, the effect of Sc additions is mainly studied in this case. Fig. 6. A, B shows the wear performance of sample $\mathrm{F}$ and sample I. It can be seen from the graph that lower Sc content exhibited higher wear loss suggesting that $0.25 \% \mathrm{Sc}$ are not sufficient for improving the both hardness or wear resistance properties. However, $0.6 \mathrm{Sc}$ additions certainly exhibited better wear resistance when compared to all other alloys. The presence of $\mathrm{Al}_{3} \mathrm{Sc}$ precipitates are responsible for this better wear resistance property since these precipitates are able to absorb the load and load transformation to the matrix gets minimized. Thus this alloy exhibited better wear resistance. In addition, the TiN particles also play significant role in change the wear performance of MMCs. Sample I experienced a wear loss of $25 \mu \mathrm{m}$ which is 3 times lower than the sample D (Fig. 6. A), whereas the sample $\mathrm{F}$ experienced a wear loss of $\sim 32 \mu \mathrm{m}$ which are very close to sample I wear loss (Fig. 6. B). These results are compared to each other since the TiN concentration is same and only the sc content is changed.

\section{Conclusions}

Al-4Cu-TiN (10, 20, $30 \mathrm{wt} \%)$ MMCs with and without Sc were successfully sintered (pressure less) at $620^{\circ} \mathrm{C}$ for 20 minutes in the controlled (Ar) atmosphere furnace. Microstructural results suggest that TiN particulates are uniformly distributed in the $\mathrm{Al}$ matrix and no debonding is observed between the particulates and matrix. Increase in the TiN content is not only responsible for improvement in hardness values but also exhibited superior wear resistance properties. In addition, higher Sc content $(0.6 \mathrm{wt} \%)$ is responsible for further improvement in mechanical and tribological properties. Even though the coefficient of friction and temperature changes due to additions of Sc to Al-TiN MMCs and varying load have been made, it is not discussed here.

\section{Acknowledgments}

The authors wish to thank Prof. S. P. Mehrotra, Director of National Metallurgical Laboratory for his kind permission to publish this paper. We sincerely thank Mr. M. K. Gunjan and Mr. B. Mahato for SEM and XRD studies respectively. We also would like to thank Mr. G. Vimalan, Mr. K. Seetharaman and Mr. Y. P. K. Rao, of NML, Jamshedpur for their technical support.

References

[1] Lloyd, D. J: Particle reinforced aluminum and magnesium matrix composites, Int. Mater. Rev, 1994, Vol. 39, pp.1-23

[2] Rohatgi, P. K - Asthana, R. - Das, S: Future directions in solidification of metal matrix composites, Int. Met. Rev, 1986, Vol. 31, pp. 115-139

[3] Ibrahim, I. A - Mohammad, F. A. - Laverni E. J.: Particulate reinforced metal matrix composites - a review, J. Mater. Sci, 1991, Vol. 26, pp. 1137-1156.

[4] Kelly, A.: Composites in context, Compos. Sci. Technol, 1985, Vol.23, pp. 171-199.

[5] Akio, K. - Atsushi, O. - Toshori, K. - Horoyuki, T.: Fabrication process of metal matrix composite with nano-size SiC particle produced by vortex method, J Japan Institute Light Metals, 1999, Vol. 49, pp. 149-154.

[6] Shyua, R. F. - Wenga, F. T. - Ho, C. T.: In situ, reacted titanium nitride-reinforced aluminum alloy composite, J Mater Proc Tech, 2002, Vol. 122, pp. 301-304.

[7] Gao, Y. - Jia, J. - Loehman, R. E. - Ewsuk, K. G.: Transmission electron microscopy study of $\mathrm{Al} / \mathrm{Al}_{2} \mathrm{O}_{3}$ composites fabricated by reactive metal infiltration, J.Mater. Res, 1995, Vol. 10, pp. 1216-1225.

[8] Kim, I. S. - Hennicke, H. K.: Oxidationsverhalten von der Schmelze einer AlSiMg-Leigierung, Aluminium, 1993, Vol.69, pp. 269-272.

[9] Jiang, J. Q. - Ma, A. B. - Liu, H. N. - Tan, R. S.: Fabrication of alumina short fiber reinforced aluminum alloy via centrifugal force infiltration, Mater. Sci. Tech, 1994, Vol. 10, pp. 783-787.

[10] Wu, Y. - Lavernia, E. J.: Spray atomization and co deposited $6061 \mathrm{Al} / \mathrm{SiCP}$ composites, J. Met, 1991, Vol. 43, pp. 16-23.

[11] Thakur, S. K. - Kong, T. S.: Gupta M, Microwave synthesis and characterization of metastable $(\mathrm{Al} / \mathrm{Ti})$ and hybrid $(\mathrm{Al} / \mathrm{Ti}+\mathrm{SiC})$ composite, Mat Sci Engg A, 2007, Vol. 452, pp.61-69.

[12] Ajoy Kumar, R. - Venkateswarlu, K. - Chaudhury, S. K. - Das, S. K. - Ravi Kumar, B. - Pathak, L. C.: Fabrication of TiN reinforced aluminium metal matrix composites through a powder metallurgical route, Mat Sci Engg A, 2002, Vol. 338, pp. 160-165.

[13] Xiao, P. - Derby, B.: Acta Materialia, 44 (1999) pp. 307-311.

[14] Arsenaul, J. R.: Materials Science and Engineering, Volume 64, Issue 2, June 1984, pp. 171-181.

[15] Venkateswarlu K. et al., Mater. Sci. Engg. A 383 (2004) pp. 374-380.

\section{A szkandium adalékolás hatása Al-TiN fémmátrixú társított anyagok nyomásmentes szinterelésére}

Al-TiN (10, 20, 30 m/m\%) társított anyagokat állítottunk elố nyomásmentes szintereléssel Sc adalékolás nélkül, illetve 0,2 és 0,6 m/m\% Sc adalékolásával. A jobb nedvesíthetôség érdekében valamennyi mintába $4 \mathrm{~m} / \mathrm{m} \%$ Cu-t is bekevertünk. A kísérletek során az Al, Cu és TiN porokat alaposan összekevertük, majd a porelegybôl 12 mm átmérójú, 4 mm vastag pasztillákat készítettünk. Az így kapott mintákat csőkemencében, argon áramban 450,550 és $620^{\circ} \mathrm{C}$-on szintereltük. Azt tapasztaltuk, hogy a nagyobb TiN tartalmú, illetve a $620^{\circ} \mathrm{C}$-on szinterelt minták keménysége jobb volt a többi mintáénál. Az alacsonyabb hômérsékleteken szinterelt pasztillák kis keménysége nem teljes zsugorodásra utal. A Sc-mal adalékolt mintákat ezért $620^{\circ} \mathrm{C}$-on szintereltük. A 0,2 m/m\% Sc-t tartalmazó mintáknál sem a mikroszerkezet, sem a keménység nem javult. Ugyanakkor a 0,6 m/m\% Sc-t tartalmazó mintáknál a keménység jelentôsen megnövekedett. Ezek a minták nagyon finom szemcseszerkezetũek, és bennük erôs felületi kötések alakultak ki az Al mátrix és a TiN részecskék között. A legnagyobb keménységet és a legjobb mikroszerkezetet az Al-0,6Sc-30TiN mintánál tapasztaltuk. A társított rendszerek kopási viselkedésének vizsgálata során megállapítottuk, hogy a Sc adalékolás nemcsak a mikroszerkezetet, hanem a kopási tulajdonságokat is javítja.

Ref.: http://dx.doi.org//10.14382/epitoanyag-jsbcm.2010.8

Khare, S. - Sharma, M. - Venkateswarlu, K.: Effect of scandium additions on pressure less sintering of Al-TiN metal mat-rix composites. Építőanyag, 61. évf. 2. szám (2010), 39-42. p. 